\title{
Regenerative therapy for hypoplastic left heart syndrome: First report of intraoperative intramyocardial injection of autologous umbilical-cord blood-derived cells
}

\author{
Harold M. Burkhart, MD, ${ }^{\mathrm{a}}$ Muhammad Yasir Qureshi, MBBS, ${ }^{\mathrm{b}}$ Susana Cantero Peral, MD,,${ }^{\mathrm{c} d}$ \\ Patrick W. O'Leary, MD, ${ }^{\mathrm{b}}$ Timothy M. Olson, MD, ${ }^{\mathrm{b}}$ Frank Cetta, MD, ${ }^{\mathrm{b}}$ and \\ Timothy J. Nelson, MD, PhD, ${ }^{\text {b,c, }, \mathrm{e}, \mathrm{f}}$ the Wanek Program Clinical Pipeline Group, Rochester, Minn
}

Video clip is available online.

The current standard of care for neonates with hypoplastic left heart syndrome (HLHS) includes a series of cardiac operations culminating in a complete cavopulmonary connection. Given the increased workload placed on the right ventricle, development of ventricular dysfunction and heart failure are concerns. As this patient population ages, many may require cardiac transplantation. Cellbased strategies to treat heart failure in adults have been reported, but little is known about their feasibility and efficacy in children with congenital heart disease. In an effort to attenuate or prevent the progression of heart failure that leads to the need for cardiac transplantation, we have developed an autologous cell-based protocol for infants with HLHS. We present the first reported case of direct intramyocardial injection of umbilical-cord blood-derived mononuclear cells in an infant with HLHS undergoing stage-II surgical palliation.

\section{CASE HISTORY}

Prenatal diagnosis of HLHS was established by fetal echocardiography at 26 weeks of gestation. The family enrolled in Mayo Clinic's (Rochester, Minn) phase-I study

From the Divisions of Cardiovascular Surgery, ${ }^{\mathrm{a}}$ Pediatric Cardiology, ${ }^{\mathrm{b}}$ and General Internal Medicine, ${ }^{\mathrm{c}}$ Department of Molecular Pharmacology and Experimental Therapeutics, ${ }^{\mathrm{d}}$ Transplant Center, ${ }^{\mathrm{e}}$ and Center for Regenerative Medicine, ${ }^{\mathrm{f}}$ Mayo Clinic, Rochester, Minn.

This work was supported by the Todd and Karen Wanek Program for Hypoplastic Left Heart Syndrome, Mayo Clinic Foundation, Rochester, Minn

Disclosures: Authors have nothing to disclose with regard to commercial support.

Wanek Program Clinical Pipeline Group: Julia Thebiay, Matt Hoplin, Karen Miller, Muhammad Y. Qureshi, Andre Terzic, Darcie J. Radel, Allen B. Dietz, Patrick W. O'Leary, Timothy M. Olson, and Timothy J. Nelson.

Received for publication Oct 14, 2014; accepted for publication Oct 20, 2014; available ahead of print Nov 20, 2014

Address for reprints: Harold M. Burkhart, MD, Department of Surgery, University of Oklahoma Health Sciences Center, 920 Stanton L. Young Blvd., WP2230,

Oklahoma City, OK 73104 (E-mail: harold-burkhart@ouhsc.edu).

J Thorac Cardiovasc Surg 2015;149:e35-7

$0022-5223 / \$ 36.00$

Copyright (c) 2015 by The American Association for Thoracic Surgery

http://dx.doi.org/10.1016/j.jtcvs.2014.10.093 of autologous umbilical-cord blood cells for HLHS. The study followed a protocol approved by the US Food and Drug Administration and an institutional review board, after written informed consent was obtained from participants. Umbilical-cord blood was collected at the time of delivery and processed in the Human Cell Therapy Laboratory at Mayo Clinic to achieve release criteria of the mononuclear cell fraction. Postnatal transthoracic echocardiography confirmed the diagnosis of HLHS with severe mitral stenosis, aortic atresia, and severe left ventricular hypoplasia. The neonate underwent Norwood procedure with Sano modification on the fourth day of life. The postoperative course was uncomplicated, and the neonate was discharged on day 13 of life.

Follow-up echocardiography at age 3 months demonstrated recurrent coarctation of the aorta with a systolic mean Doppler gradient of $21 \mathrm{~mm} \mathrm{Hg}$ (corrected maximum instantaneous gradient $=32 \mathrm{~mm} \mathrm{Hg}$ ). Right ventricular systolic function was moderately reduced, with an estimated ejection fraction of $35 \%$. The infant underwent cardiac catheterization and balloon aortoplasty, which reduced the peak-to-peak gradient from 14 to $5 \mathrm{~mm} \mathrm{Hg}$. Balloon angioplasty of the right pulmonary artery was also attempted, to relieve proximal stenosis.

At age 4 months, the patient was evaluated in preparation for stage-II palliation. Preoperative 24-hour Holter monitoring did not detect any arrhythmia. Echocardiographic evaluation demonstrated persistent right ventricular systolic dysfunction, with an estimated ejection fraction of $30 \%-35 \%$. No evidence was found of residual coarctation, and only trivial neoaortic and tricuspid valve regurgitation were present. Laboratory studies showed an NT-Pro-BNP (N-terminal of the prohormone brain natriuretic peptide) level of $28,148 \mathrm{pg} / \mathrm{mL}$, a troponin $\mathrm{T}$ level of $0.13 \mathrm{ng} / \mathrm{mL}$, and a creatine kinase (CK)-MB level of $7.1 \mathrm{ng} / \mathrm{mL}$.

The infant underwent stage-II surgical palliation, consisting of bidirectional cavopulmonary anastomosis, and patch augmentation with intraoperative stent placement in the right pulmonary artery. After successful separation from cardiopulmonary bypass, an autologous cell-based, manufactured product was transplanted into the right ventricular free wall, according to the study protocol. A 


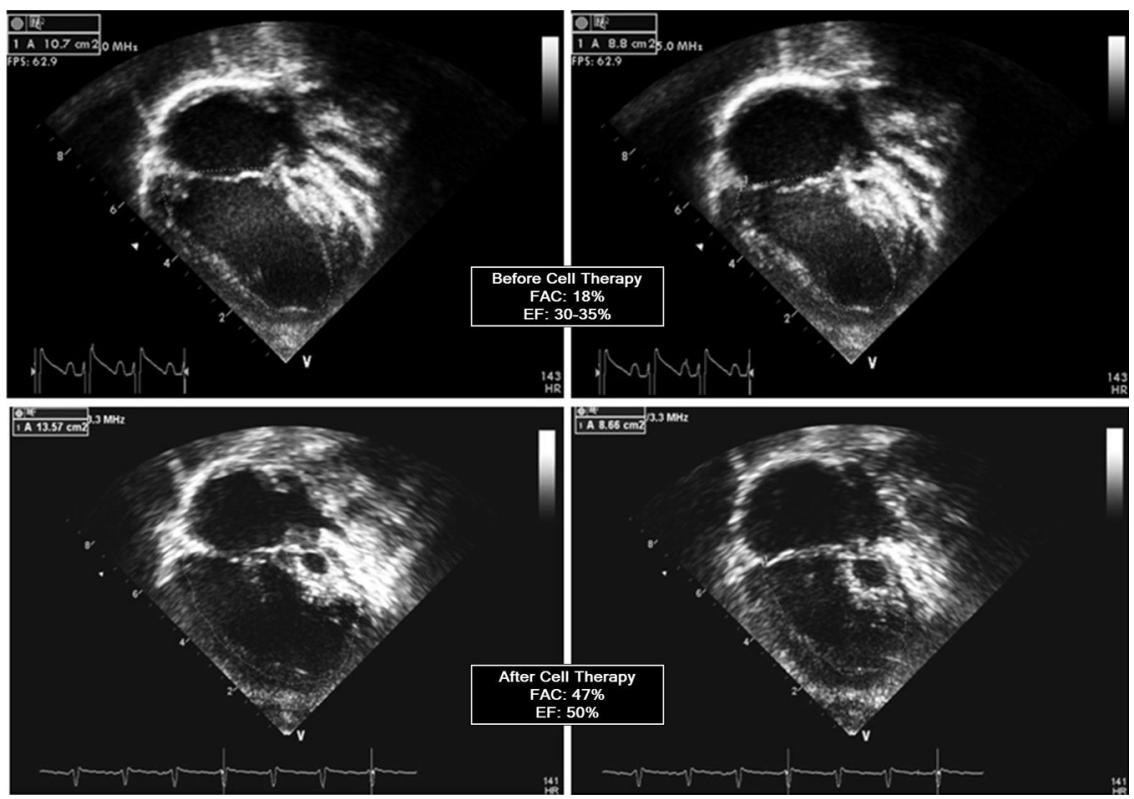

FIGURE 1. Apical views of echocardiogram performed before (top panels) and 3 months after (bottom panels) intramyocardial injection of umbilical-cord blood-derived stem cells. Images show improvement in right ventricular function, with an increase in the ejection fraction from $30 \%-35 \%$ to $50 \%$. $F A C$, Fractional area change; $E F$, ejection fraction.

radial pattern of 6 injections was made $2 \mathrm{~mm}$ below the surface of the epicardium of the right ventricle. The cells were delivered in $0.6 \mathrm{ml}(0.1 \mathrm{~mL}$ per injection site $)$ of a solution containing 30 million cells $/ \mathrm{ml}$, to achieve the target dose of 3 million cells $/ \mathrm{kg}$ of body weight. No bleeding, arrhythmia, or hemodynamic changes occurred during the injections.

Troponin T peaked at 3 hours postsurgery, at $2.8 \mathrm{ng} / \mathrm{mL}$. Postoperative transesophageal echocardiography showed persistent, stable, right ventricular systolic dysfunction (with an estimated ejection fraction of 30\%). The postoperative course was complicated by Klebsiella $\mathrm{sp}$ and Citrobacter sp respiratory infections, which were successfully treated with intravenous antibiotics. Ten

TABLE 1. Summary of echocardiographic parameters of right ventricular function before and after cell-based therapy

\begin{tabular}{|c|c|c|}
\hline Assessment & $\begin{array}{l}\text { Before cell-based } \\
\text { therapy }\end{array}$ & $\begin{array}{l}3 \text { months after } \\
\text { cell-based therapy }\end{array}$ \\
\hline \multicolumn{3}{|l|}{ Quantitative } \\
\hline Fractional area change & $18 \%$ & $47 \%$ \\
\hline $\begin{array}{l}\text { Tricuspid valve, annular } \\
\text { systolic velocity }\end{array}$ & $4 \mathrm{~cm} / \mathrm{s}$ & $6 \mathrm{~cm} / \mathrm{s}$ \\
\hline $\begin{array}{l}\text { Tricuspid valve, annular } \\
\text { plane systolic excursion }\end{array}$ & $6 \mathrm{~mm}$ & $8 \mathrm{~mm}$ \\
\hline \multicolumn{3}{|l|}{ Qualitative } \\
\hline Right ventricular function & $\begin{array}{l}\text { Moderately } \\
\text { reduced }\end{array}$ & Normal \\
\hline $\begin{array}{l}\text { Right ventricular ejection } \\
\text { fraction }\end{array}$ & $30 \%-35 \%$ & $50 \%$ \\
\hline
\end{tabular}

days after the surgery, the infant developed necrotizing enterocolitis with bowel perforation. Partial transverse colon resection and end-colostomy at hepatic flexure was performed. The infant was eventually discharged 3 weeks after the abdominal surgery. Daily review of telemetry did not demonstrate any sustained or serious arrhythmia.

Per study protocol, follow-up evaluations were performed at 1 and 3 months after autologous cell delivery. The patient had one episode of otitis media and conjunctivitis requiring antibiotic therapy. Outpatient 24-hour Holter monitoring did not demonstrate any arrhythmia. Laboratory evaluation at 1 month showed an NT-Pro-BNP level of $1175 \mathrm{pg} / \mathrm{mL}$, and a CK-MB level of $4.1 \mathrm{ng} / \mathrm{mL}$; troponin $\mathrm{T}$ was undetectable. Transthoracic echocardiography at 3 months showed improvement in right ventricular systolic function, with an estimated ejection fraction of 50\% (Figure 1; Table 1; Video 1).

\section{COMMENTS}

Although surgical results for the treatment of HLHS have improved, patients are still at significant risk for developing right ventricular failure and eventually needing cardiac transplantation. Regenerative cellular strategies designed to minimize the risk of long-term ventricular failure in these infants who have single-ventricle circulations are a promising new therapy. The overwhelming majority of literature regarding cell-based cardiac therapy pertains to adult patients with acute and chronic ischemic heart diseases. Jeevanantham and 
colleagues $^{1}$ reported a meta-analysis of 50 studies analyzing intracoronary and intramyocardial bone marrow-derived cell transplantation in a total of 2625 patients with acute and chronic ischemic heart disease. Their review concluded that all-cause mortality, cardiac mortality, and the incidence of recurrent myocardial infarction and stent thrombosis were significantly lower in the bone-marrow cell-treated group compared with control subjects. Overall, most studies concluded that intracoronary and intramyocardial bone-marrow mononuclear cell infusion was safe in adult patients. ${ }^{2-8}$

Experience with cell-based therapy in children with severe congenital or acquired heart disease is limited. To date, no large clinical trials have been reported using any type of cell-based strategy in congenital heart disease. Rupp and colleagues ${ }^{9}$ reported intracoronary delivery of bone marrow-derived mononuclear cells in 9 children with advanced heart failure, with more than half showing improvement in their clinical condition. Additionally, 2 case reports suggest an improvement in heart function, as measured by ejection fraction and clinical stability, after intracoronary, autologous, bone marrow-derived, mononuclear cell administration in children with HLHS and dilated cardiomyopathy. ${ }^{10,11}$ A 1-year follow-up study of 6 pediatric patients with dilated cardiomyopathy who received intramyocardial bone marrow-derived stem cell transplantation was recently published. ${ }^{12}$ No arrhythmia or any other adverse effects were observed after the cell therapy. The average basal left ventricular ejection fraction was $33.5 \%$, which increased to $54 \%$ in a 6 -month period, and up to $54.5 \%$ after 1 year. ${ }^{12}$

The primary goal for the current study of cardiac regenerative therapies for HLHS was to determine the safety and feasibility of autologous umbilical-cord bloodderived mononuclear cell delivery into the right-ventricle myocardium during planned, stage-II surgical palliation. This protocol avoids the need for additional procedures by utilizing an add-on cell delivery strategy of intramyocardial injections under direct visualization at the time of planned operation. Although the reported patient developed postoperative complications, these events were not attributed to the cell-based protocol.

An encouraging finding was the progressive improvement in the right ventricular ejection fraction during the 3-month interval following cell-based therapy. Whether this improvement resulted solely from the regenerative therapy, or from relief of recurrent arch obstruction, or from a combination of both, is difficult to determine. However, depressed ventricular function persisted at the time of surgery, nearly 1 month after successful aortic balloon dilation. Future studies and longer follow-up are needed to establish the efficacy and safety of intramyocardial injection of umbilical cord-derived mononuclear cells in HLHS.

\section{References}

1. Jeevanantham V, Butler M, Saad A, Abdel-Latif A, Zuba-Surma EK, Dawn B. Adult bone marrow cell therapy improves survival and induces long-term improvement in cardiac parameters: a systematic review and meta-analysis. Circulation. 2012;126:551-68.

2. Delewi R, Hirsch A, Tijssen JG, Schächinger V, Wojakowski W, Roncalli J, et al. Impact of intracoronary bone marrow cell therapy on left ventricular function in the setting of ST-segment elevation myocardial infarction: a collaborative meta-analysis. Eur Heart J. 2014;35:989-98.

3. Zimmet H, Porapakkham P, Porapakkham P, Sata Y, Haas SJ, Itescu S, et al. Short- and long-term outcomes of intracoronary and endogenously mobilized bone marrow stem cells in the treatment of ST-segment elevation myocardial infarction: a meta-analysis of randomized control trials. Eur J Heart Fail. 2012;14:91-105

4. Zhang C, Sun A, Zhang S, Yao K, Wu C, Fu M, et al. Efficacy and safety of intracoronary autologous bone marrow-derived cell transplantation in patients with acute myocardial infarction: insights from randomized controlled trials with 12 or more months follow-up. Clin Cardiol. 2010;33:353-60.

5. Martin-Rendon E, Brunskill SJ, Hyde CJ, Stanworth SJ, Mathur A, Watt SM. Autologous bone marrow stem cells to treat acute myocardial infarction: a systematic review. Eur Heart J. 2008;29:1807-18.

6. Lipinski MJ, Biondi-Zoccai GG, Abbate A, Khianey R, Sheiban I, Bartunek J, et al. Impact of intracoronary cell therapy on left ventricular function in the setting of acute myocardial infarction: a collaborative systematic review and meta-analysis of controlled clinical trials. J Am Coll Cardiol. 2007;50: 1761-7.

7. Wen Y, Meng L, Xie J, Ouyang J. Direct autologous bone marrow-derived stem cell transplantation for ischemic heart disease: a meta-analysis. Expert Opin Biol Ther. 2011;11:559-67.

8. Donndorf P, Kundt G, Kaminski A, Yerebakan C, Liebold A, Steinhoff G, et al. Intramyocardial bone marrow stem cell transplantation during coronary artery bypass surgery: a meta-analysis. J Thorac Cardiovasc Surg. 2011;142:911-20.

9. Rupp S, Jux C, Bönig H, Bauer J, Tonn T, Seifried E, et al. Intracoronary bone marrow cell application for terminal heart failure in children. Cardiol Young. 2012;22:558-63

10. Rupp S, Bauer J, Tonn T, Schächinger V, Dimmeler S, Zeiher AM, et al. Intracoronary administration of autologous bone marrow-derived progenitor cells in a critically ill two-yr-old child with dilated cardiomyopathy. Pediatr Transplant. 2009;13:620-3.

11. Rupp S, Zeiher AM, Dimmeler S, Tonn T, Bauer J, Jux C, et al. A regenerative strategy for heart failure in hypoplastic left heart syndrome: intracoronary administration of autologous bone marrow-derived progenitor cells. J Heart Lung Transplant. 2010;29:574-7.

12. Bergmane I, Lacis A, Lubaua I, Jakobsons E, Erglis A. Follow-up of the patients after stem cell transplantation for pediatric dilated cardiomyopathy. Pediatr Transplant. 2013;17:266-70. 